\title{
PENERAPAN APLIKASI MSBE SEBAGAI MEDIA ALAT BANTU GURU BIMBINGAN KONSELING PADA SMK FADILAH
}

\author{
Ruli Supriati ${ }^{1}$ \\ Nirwan Salim ${ }^{2}$ \\ Ramdani Sofhan ${ }^{3}$ \\ Email: ruli@ raharja.info, nirwansalim01@gmail.com, \\ ninoraymon88@yahoo.com
}

ABSTRAK

Penelitian ini bertujuan untuk membantu meringankan tugas guru Konseling. Karena di lembaga pendidikan seperti sekolah dalam semua kegiatan mereka tidak terlepas dari peran guru, seperti peran Konseling guru. Konseling adalah tugas guru untuk bekerja dengan siswa yang memiliki masalah. Dimana siswa yang memiliki masalah dalam kebutuhan sehari-hari mereka dari perhatian khusus pada masalah yang telah dilakukan, terbatasnya jumlah guru BK merupakan kendala dalam memantau siswa bermasalah. Monitoring siswa bermasalah berbasis aplikasi di situs ini digunakan sebagai alat untuk memantau keadaan siswa. Dengan aplikasi ini, terutama di bidang konseling sekolah dapat memantau dan melaporkan kondisi siswa terlibat dalam kesulitan dan memfasilitasi orang tua untuk mendapatkan informasi tentang aktivitas atau kegiatan anak-anak mereka saat berada di sekolah.

Kata kunci: konseling guru, pendidikan, pemantauan, siswa bermasalah, pemantauan

ABSTRACT

This research aims to help alleviate the task of teachers Counseling. Because in an educational institution such as a school in all their activities can not be separated from the role of a teacher, such as the role of teacher's Counseling. Counseling is the task of teachers to work with students who have problems. Where students who have problems in their daily need of special attention on the problem that has been done, the limited number of teachers $B K$ is a constraint in monitoring troubled students. Application-based monitoring troubled students on this website is used as a tool to monitor the state of the student. With this application, especially in the field of school counseling can monitor and report on the condition of students getting in trouble and facilitate parents to get information about the activity or activities of their children while in school.

Keywords: teacher counseling, education, monitoring, troubled students, monitoring

\section{PENDAHULUAN}

Dalam sebuah instansi pendidikan seperti sekolah tidak terlepas dari peran seorang guru Bimbingan Konseling yang merupakan salah satu komponen dari pendidikan. Tujuan Bimbingan Konseling di sekolah adalah membantu peserta didik untuk mengembangkan pemahaman diri sesuai dengan kecakapan, minat pribadi, hasil belajar serta kesempatan yang ada, membantu peserta didik dalam penyesuaian diri terhadap dirinya maupun lingkungannya serta mengembangkan kemampuan dan potensi yang dimilikinya. Peserta didik yang berhasil memahami pribadinya serta kehidupannya akan lebih menghargai dan menjamin kehidupannya yang lebih efektif dan lebih kearah yang positif.

Sedangkan peserta didik yang belum bisa memahami pribadinya serta kehidupannya akan berprilaku sedikit menyimpang dan cenderung ke arah negatif. Dan peserta didik seperti inilah yang cenderung bermasalah dilingkungan sekolah. Peserta didik yang bermasalah membutuhkan perhatian yang khusus mengenai permasalahannya. Terbatasnya pembimbing konseling di SMK

Vol.1 No.1 - Agustus 2015 
Fadilah yang terdiri dari satu orang menjadi permasalahan dalam kegiatan memantau kegiatan siswa. Guru BK masih kesulitan dalam menangani masalah yang ada karena tugas guru BK tidak hanya memberikankonseling terhadap siswa tetapi juga mempunyai tugas mengajar di kelas dan tugas-tugas lainnya. Guru Bimbingan Konseling membutuhkan alat bantu untuk meringankan tugas guru Bimbingan Konseling yang awalnya dilakukan secara manual yaitu dengan mencatat seluruh kejadian atau masalah siswa kedalam buku dan melakukan perhitungan secara manual. Dengan alat bantu ini, tugas guru BK akan sedikit berkurang terutama dalam memantau kegiatan siswa serta merekapitulasi hasil monitoring siswa.

Dari uraian tersebut menunjukan bahwa kehadiran media informasi berbasis website diperlukan untuk membantu tugas setiap individu. Salah satu faktor yang ada diluar individu adalah tersedianya media alat bantu monitoring yang memberi kemudahan bagi individu atau organisasi untuk memonitoring aktivitasnya, sehingga menghasilkan laporan atau output yang lebih baik.

Kriteria dalam menentukan siswa bermasalah meliputi nilai akademik, pelanggaran tata tertib sekolah serta permasalahan diluar sekolah. Kriteria ini akan memberikan bobot penilaian tiap siswa yang nantinya dihitung dengan metode tertentu sehingga menghasilkan data mengenai siswa yang bermasalah. Metode untuk menentukan data tersebut bisa dilakukan dengan metode Certainty Factor. Metode Certainty Factor merupakan metode yang bersifat akurat yaitu dengan menghitung probabilitas tingkat keyakinan dan ketidakyakinan terhadap sebuah fakta (Budhi, 2008). Metode Certainty Factor hanya menghitung dua data saja dalam setiap perhitungan sehingga keakuratan informasi dapat terjaga.

Metode penelitian yang digunakan adalah Penelitian ekspos facto yaitu metode yang meneliti hubungan antara sebab dan akibat. Penelitian ini dilakukan terhadap program, kejadian atau kegiatan yang sudah berlangsung atau telah terjadi.

\section{LANDASAN TEORI}

\section{Definisi Monitoring}

Monitoring (pemantauan) merupakan sebuah proses penaksiran atau penilaian kualitas kinerja sistem dari waktu ke waktu. Pemantauan ini dilakukan secara berkelanjutan sejalan dengan kegiatan usaha yang mencakup kegiatan sehari hari (Tampubolon, 2005). Pengawasan adalah pengendalian yang dilakukan dengan melaksanakan pemeriksaan, penilaian kemampuan, meningkatkan dan menyempurnakan, baik manajemen maupun bidang operasionalnya (Rusyani, 1997). Penggunaan sistem monitoring bertujuan untuk dapat mengontrol, mengawasi serta mengecek sejumlah aktivitas yang telah dilakukan (Tan, 2010).

Dari beberapa pengertian di atas dapat disimpulkan bahwa monitoring adalah proses pengumpulan informasi secara berkelanjutan dengan tujuan untuk dapat mengawasi kegiatan yang telah dilakukan guna meningkatkan dan menyempurnakan tujuan yang akan dicapai.

\section{Definisi Siswa Bermasalah}

Seorang siswa diketegorikan sebagai siswa yang bermasalah apabila ia menunjukkan gejala-gejala penyimpangan dari perilaku yang lazim dilakukan oleh siswa pada umumnya baik penyimpangan perilaku yang sederhana seperti: mengantuk, suka menyendiri atau terlambat datang maupun penyimpangan yang bersifat ekstrim seperti: membolos, memeras atau biasa disebut memalak ataupun tidak sopan kepada orang lain juga kepada gurunya. Bentuk masalah yang dihadirkan siswa dapat dibagi menjadi dua sifat yaitu, sifat regresif antara lain: pemalu, penakut, mengantuk, tidak mau sekolah dan sifat agresif antara lain: berbohong, membuat onar, memeras, beringas dan perilaku-perilaku lain yang bisa menarik perhatian orang lain (Mustaqim, 2003).

Secara garis besar pangkal persoalan masalahmasalah siswa dapat dikelompokkan menjadi dua, yaitu :

\section{Internal}

Sebab-sebab internal adalah masalah yang berpangkal dari kondisi siswa itu sendiri. Hal ini bisa bermula dari adanya kelainan 
fisik seperti: gemuk, cacat lahir, maupun psikis yang merupakan kelainan yang terjadi pada kemampuan berpikir (kecerdasan) seorang siswa.

\section{Eksternal}

Sebab-sebab internal adalah masalah yang hadir dari luar siswa. Sebab-sebab eksternal berpangkal dari keluarga, pergaulan, salah asuh atau pengalaman hidup yang tidak menyenangkan.

\section{Definisi Monitoring Siswa Bermasalah}

Siswa yang bermasalah mempunyai latar belakang yang berbeda-beda, mereka harus dipahami mengenai latar belakang masalahnya, bentuk-bentuk masalahnya sekaligus teknikteknik penangananya (Mustaqim, 2003). Monitoring atau pengawasan mempunyai peran sebagai pengendali keberhasilan tujuan yang telah ditetapkan sebelumnya. Pengendali disini berupa kepastian pelaksanaan kependidikan, penilaian dan penelaah fakta kegiatan, koreksi dan motivasi rencana agar sejalan dengan perubahan yang mungkin terjadi (Rusyani, 1997).

Monitoring siswa bermasalah adalah proses pengawasan seluruh kegiatan siswa dengan tujuan untuk mencegah terjadinya penyimpangan penyimpangan yang mempengaruhi tujuan kegiatan belajar mengajar. Dengan demikian pihak sekolah khususnya Bimbingan Konseling secara dini bisa mengambil tindakan terbaik untuk mengatasi penyimpangan tersebut agar tidak terjadi penyimpangan yang lebih luas.

\section{LITERATURE REVIEW}

Banyak penelitian yang sebelumnya dilakukan mengenai Monitoring Siswa Bermasalah.Untuk mengidentifikasikan metode yang pernah dilakukan, serta mengetahui orang lain yang spesialisasi dan area penelitian yang sama dibidang ini. Beberapa Literature Review tersebut adalah:

1. Penelitian yang dilakukan oleh Moch. Arifin, S.Pd., M.Si dan Yohanes Budi
Hartoyo pada tahun 2009 dengan judul "Monitoring Siswa Bermasalah Menggunakan Metode Certainty Factor" Penelitian ini membahas tentang memonitoring siswa yang bermasalah berdasarkan kategori yang telah ada dan menganalisanya menggunakan metode Certainty Faktor untuk mendapatkan hasil yang akurat. Sehingga diusahakan tidak terjadi kerancuan dalam hasil monitoringnya. Metode Certainty Faktor ini masih jarang digunakan untuk aplikasi monitoring. Dan ternyata dapat dibuktikan bahwa metode ini berjalan dengan baik di aplikasi monitoring ini.

2. Penelitian yang dilakukan oleh Fandi Setyo Prambudi pada tahun 2012 dengan judul "Sistem Informasi Monitoring Siswa Bermasalah Berbasis Web dan SMS Gateway". Penelitian ini membahas tentang memonitoring siswa yang bermasalah berdasarkan pelanggaran-pelanggaran berat, di penelitian ini juga sudah menerapkan metode faktor kepastian (CertaintyFactor) sebagai metode untuk perhitungan pelanggaran yang dilakukan oleh siswa supaya mendapatkan hasil yang akurat dan juga sudah menerapkan sms gateway untuk penyampaian informasi ke orang tua siswa, sehingga orang tua siswa mendapatkan informasi tentang aktivitas anaknya di sekolah.

3. Penelitian yang dilakukan oleh Suci Wuri Handayanipada tahun 2009 dengan judul "Upaya Guru Bimbingan Dan Konseling Dalam Mengatasi Siswa Bermasalah". Penelitian ini membahas tentang upaya yang dilakukan guru Bimbingan dan Konseling dalam menangani siswa yang bermasalah meliputi upaya preventif, upaya respresif dan upaya kuratif, disamping itu juga dengan pendekatan personal. Antara upaya satu dengan upaya satu dengan upaya yang lain berbeda dalam setiap penanggulangannya tergantung dengan masalah yang dihadapi siswa. Adapun hasil dari upaya yang dilakukan guru Bimbingan dan Konseling adalah siswa menjadi lebih 
bersemangat dalam belajar, dapat menumbuhkan kesadaran siswa yang tidak berubah disebabkan oleh lingkungan yang tidak mendukung dan niat pada anak itu sendiri.

4. Penelitian yang dilakukan oleh Ikhsan pada tahun 2012 dengan judul "Sistem Informasi Pengolahan Data Siswa". Penelitian ini membahas tentang pengolahan data siswa yang didalamnya Sistem menampilkan data-data siswa seperti data pribadi siswa, data siswa bermasalah, data siswa pindah, data siswa berprestasi. Keamanan informasi diberikan dengan adanya verifikasi pengguna. Memudahkan pembuatan laporan dari data pribadi siswa, data siswa bermasalah, data siswa pindah, data siswa berprestasi. Sistem ini juga akan memberikan banyak manfaat kepada admin seperti: Mengoptimalkan pekerjaan petugas sub bagian tata usaha pada pengelolaan data-data siswa. Menghemat waktu, tenaga, dan media penyimpanan dalam pengarsipan data siswa.

5. Penelitian yang dilakukan oleh Arip Munawir pada tahun 2012 dengan judul "Sistem Pakar Konsultasi Siswa Bermasalah". Penelitian ini membahas tentang bagaimana sebuah sistem dapat memberikan konseling yang nyaman dan mudah dengan menggunakan metode pencarian Depth First Search dan mesin inferensi Backward Chaining. Dapat membantu siswa untuk mengetahui secara awal permasalahan dan sebab yang dihadapinya. Dapat memberikan konseling atas permasalahan yang dihadapinya, konseling secara umum maupun konseling secara agama.

\section{PEMBAHASAN}

MSBe ini adalah aplikasi monitoring siswa bermasalah yang digunakan oleh SMK Fadilah. Banyak tools yang terdapat dalam Aplikasi MSBe ini untuk mendukung aktivitas guru bimbingan konseling di SMK Fadilah, termasuk pemantauan siswa bermasalah dan cara penanggulangannya. Tidak hanya itu, didalam aplikasi MSBe ini juga tersimpan data diri siswa seperti nomer handphone siswa, alamat nama orang tua dan juga nomer handphone orang tua siswa atau wali murid yang dapat di hubungi bila guru bimbingan konseling ingin menyampaikan informasi kepada orang tua murid atau wali murid mengenai prilaku siswa selama disekolah.

Banyak tools yang terdapat di dalam tab menu di Aplikasi MSBe yang dapat digunakan oleh guru Bimbingan Konseling SMK Fadilah untuk menunjang aktivitasnya terutama dalam proses Pemantauan siswa bermasalah, diantaranya adalah:

\section{BERANDA}

Dengan tool ini guru bimbingan konseling dapat melihat hasil monitoring yang di tampilkan dalam diagram chart. Selain itu guru bimbingan konseling juga dapat melihat urutan nama siswa yang mempunyai jumlah point pelanggaran dari yang terbesar sampai terkecil, berdasarkan kelas atau rombel tempat siswa itu berada.

\section{PTK}

Tool PTK merupakan tool data identitas diri guru-guru yang mengajar di SMK Fadilah. Dengan tool ini guru bimbingan konseling mempunyai data diri setiap guru yang berada di SMK Fadilah. Sehingga, ketika ada siswa yang mempunyai point pelanggaran yang cukup banyak, guru bimbingan konseling dapat memberitahukan kepada guru yang menjadi wali kelas dari siswa tersebut.

\section{PESERTA DIDIK}

Tool ini berisikan semua data siswa yang berada di SMK Fadilah. Dengan tool ini, guru bimbingan konseling dapat melihat identitas setiap siswa tanpa harus mencari berkas-berkasnya yang berupa hardcopy, karena semua sudah tersimpan rapih di tool ini. Ketika ada 
siswa yang bermasalah yang mengharuskan guru bimbingan konseling untuk berkomunikasi dengan orang tua siswa atau wali murid, guru bimbingan konseling bisa melihat alamat dan nomer telpon dari wali murid tersebut di tool ini.

\section{ROMBEL}

Tool ini berisikan data setiap kelas di SMK Fadilah mulai dari kelas X sampai kelas XII dan juga jurusannya, dimana isi dari kelas atau rombel ini siswa yang sudah di inputkan di tool peserta didik yang ditempatkan sesuai kelas mereka di absensi sekolah. Dan di tool ini juga guru bimbingan konseling menginput data setiap siswa yang bermasalah atau melakukan pelanggaran setiap harinya. Dari data yang berada di tool inilah yang nantinya akan di tampilkan dalam diagram monitoring yang berada di tool beranda.

\section{PDKeluar}

Tool ini berisikan peserta didik yang sudah lulus, meninggal, mutasi, hilang dan pindah atau yang dikeluarkan dari sekolah. Jadi, walaupun siswa tersebut sudah ditidak berada disekolah, data diri siswa tersebut masih tersimpan di sistem.

Alur proses jendela Login Aplikasi MSBe dalam bentuk Flowchart:

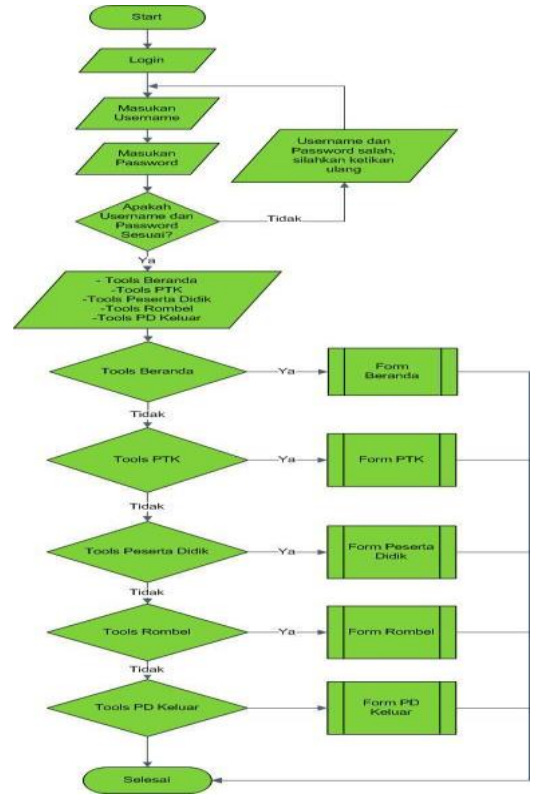

Gambar 1 Flowchart Program Untuk Login $\mathrm{MSBe}$

Dapat dijelaskan gambar 1 flowchart Program Untuk login MSBe pada "Penerapan MSBe Sebagai media alat bantu guru bimbingan konseling pada SMK Fadilah" diatas terdiri dari:

1. 2 (dua) simbol terminal, yang berperan sebagai "start" dan "selesai" pada aliran proses flowchart program pada login MSBe.

2. 4 (empat) simbol data, yang menyatakan proses input atau output tanpa tergantung jenis peralatannya, yaitu: "login", kemudian untuk login MSBe harus memasukan "username dan password", dan jika salah sistem akan memberikan data yang bertuliskan "Username dan Password salah, silahkan ketikan ulang".

3. 1 (satu) simbol decision, sebagai simbol untuk menunjukan sebuah langkah pengambilan suatu keputusan untuk mengecek validasi kebenaran username dan password, jika "ya" akan bisa masuk ke home sistem dan jika "tidak" akan kembali ke login terlebih dahulu.

4. 5 (lima) simbol subprocess sebagai simbol yang menunjukan bahwa didalam langkah yang dimaksud terdapat flowchart lain yang 
menggambarkan langkah secara rinci yang terdiri dari 5 (lima) macam-macam bagian, yaitu: Beranda, PTK, Peserta Didik, Rombel, dan PD Keluar.

\section{IMPLEMENTASI}

Tampilan aplikasi MSBe yang memiliki berbagai macam fitur yang dapat digunakan oleh guru bimbingan konseling yang terdiri dari:

a. Tampilan Login

Berikut ini tampilan Login Aplikasi MSBe

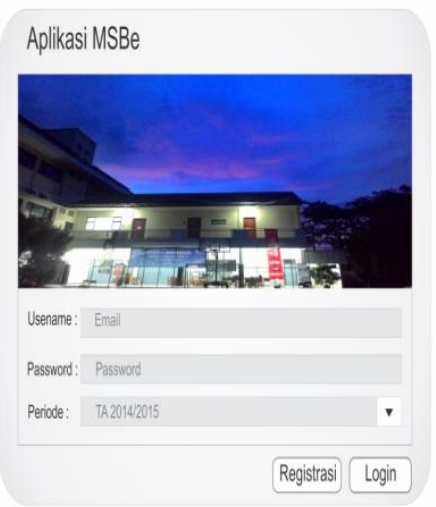

Gambar 2 Tampilan Login Ke Menu Home

b. Tampilan Tool Beranda

Berikut ini tampilan Beranda Aplikasi $\mathrm{MSBe}$, guru bimbingan konseling dapat melihat hasil monitoring dan juga mencetak hasil laporan dari sistem disini.

\section{Aplikasi MSBe}

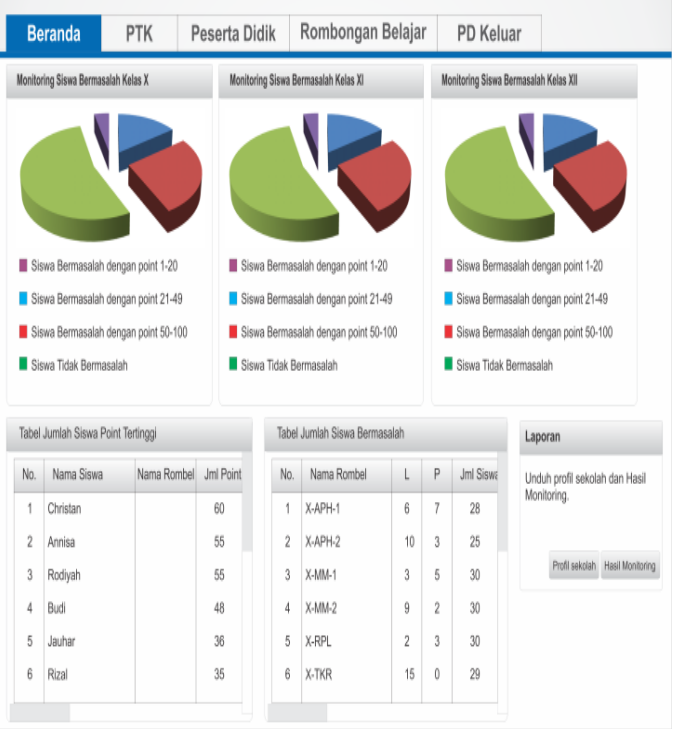

Gambar 3 Monitoring siswa bermasalah

c. Tampilan Tool PTK

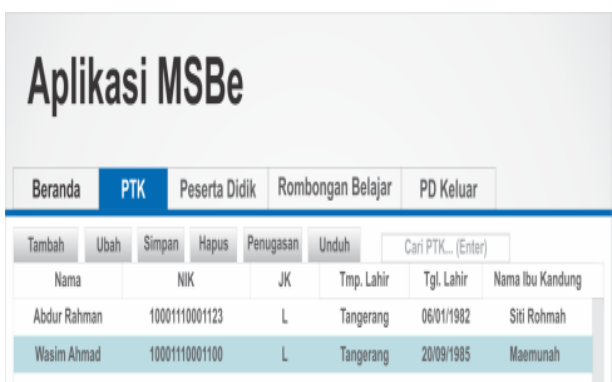

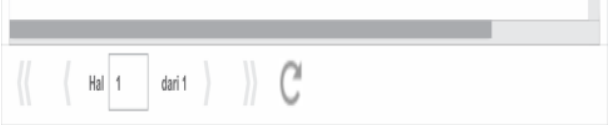


d. Tampilan Tool Peserta Didik

f. Tampilan Tool PD Keluar

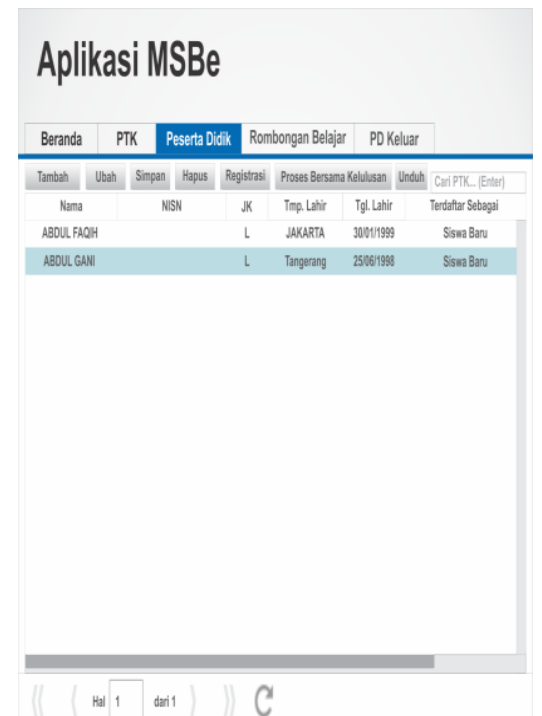

Gambar 5 Tampilan data peserta didik

e. TampilanTool Rombongan Belajar

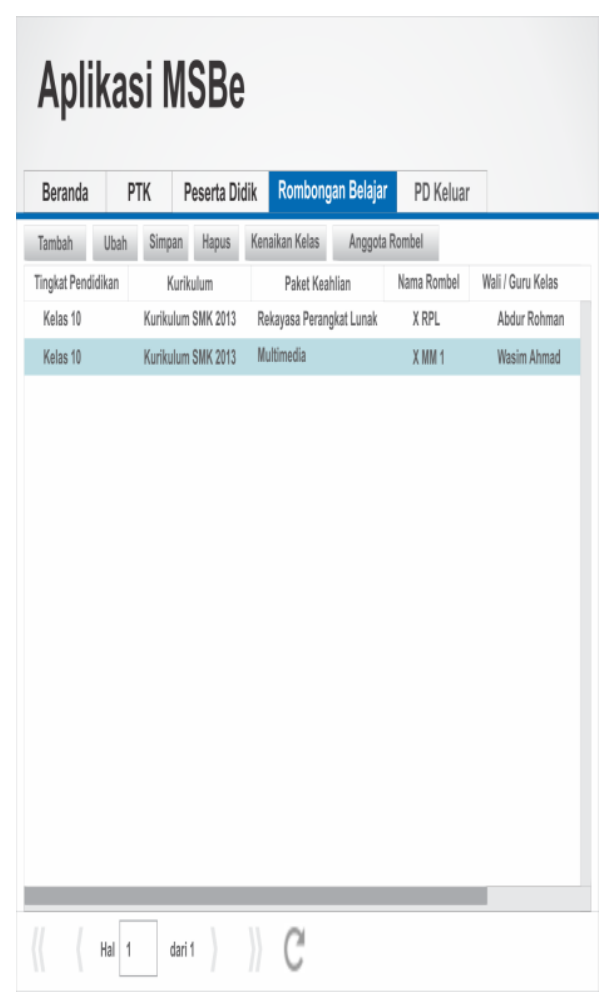

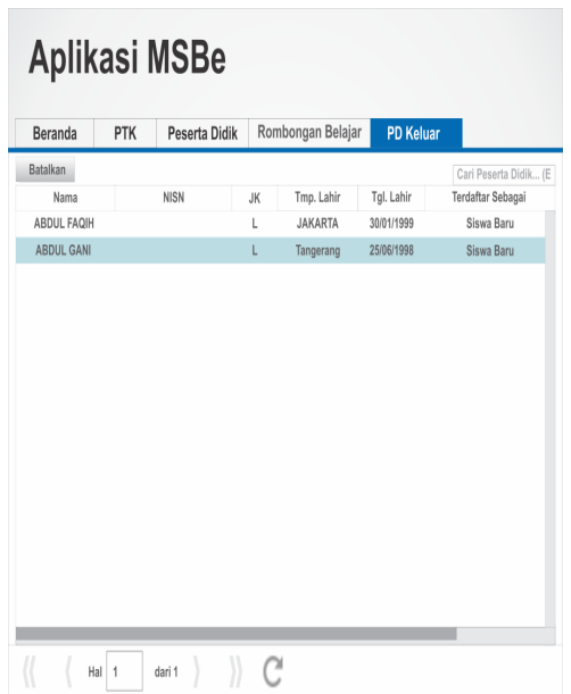

Gambar 7 Tampilan hasil dari pembinaan siswa bermasalah

g. Tampilan Menu Input

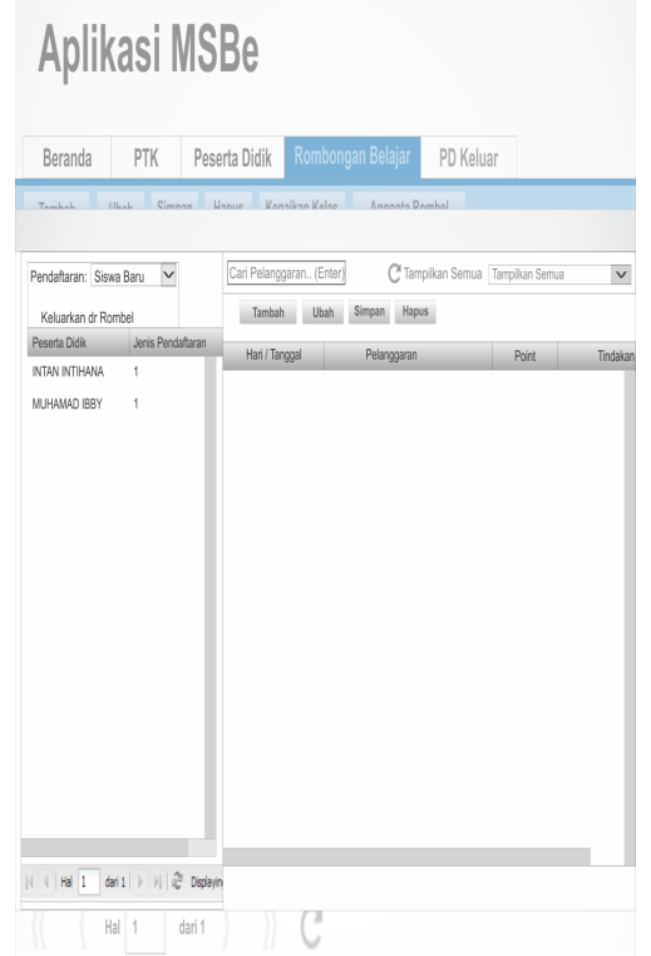


Gambar 8 Tampilan menu input pelanggaran siswa

Dari fitur yang dimiliki oleh MSBe, masih terdapat beberapa kekurangan, tetapi juga banyak memiliki kelebihan sehingga bisa menjadi media alat bantu untuk guru bimbingan konseling. Dan di bawah ini adalah uraiannya:

\section{Kelebihan}

1. Mempermudah Guru Bimbingan Konseling dalam memonitoring siswa yang bermasalah.

2. Dengan MSBe, pihak sekolah dapat meminimalisir biaya. Karena tidak perlu mencetak hard copy buku-buku pelanggaran setiap siswa disetiap kelas.

3. Data lebih akurat dan rapih

4. Data yang dibutuhkan untuk menangani siswa bermasalah lebih mudah diakses

5. Banyak tools yang tersedia di MSBe

6. Membuat laporan bulanan untuk rapat lebih mudah.

7. Untuk mengetahui jumlah siswa dan berapa pointnya lebih mudah.

\section{Kekurangan}

Keterbatasan utamanya ialah aplikasi ini memerlukan data yang harus diinputkan terlebih dahulu, seperti data identitas PTK dan Peserta Didik. Sehingga memerlukan waktu yang lumayan banyak untuk proses penginputannya. Namun dengan keterbatasan yang ada, MSBe ini tetap menawarkan fasilitas yang cukup baik sebagai media alat bantu guru bimbingan konseling.

\section{KESIMPULAN}

Dengan demikian, dapat disimpulkan bahwa penerapan MSBe ini di SMK Fadilah akan dapat mendukung aktifitas guru bimbingan konseling, khusunya dalam memonitor siswa yang bermasalah dimana sistem yang sebelumnya masih bersifat manual atau dikerjakan secara tertulis serta guru bimbingan konseling tidak perlu mengeprint buku pelanggaran pada setiap kelasnya. Dilihat dari segi keamanannya sudah baik, karena setiap user sudah diberikan hak akses sesuai dengan kebutuhannya masing-masing.

\section{DAFTAR PUSTAKA}

1. Budhi, Gregorius S. dan Intan, Rolly. 2008. "Penerapan Probabilitas Penggunaan Fakta guna menentukan Certainty Factor sebuah Rule pada Rule Base Expert System". UK Petra Surabaya jurusan Teknik Informatika Surabaya.

2. Mustaqim, dkk. 2003. "Psikologi Pendidikan.” PT. Rineka Cipta. Jakarta.

3. Rusyani, R. Tabrani. 1997. "Manajemen Pendidikan", Media Pustaka. Bandung.

4. Tampubolon, Robert. 2005. "Risk and System-Based Internal Audit". PT. Elex Media Komputindo. Jakarta.

5. Tan, Anton. 2010. "Becoming The Best Salespeople". PT. Elex Media Komputindo. Jakarta.

6. Arifin, Moch, Yohanes Budi Hartoyo, (2009) "Monitoring Siswa Bermasalah Menggunakan Metode Certainty Factor" [Online]. Tersedia di http://sir.stikom.edu/

7. Prambudi, Fandi Setyo, (2012)"Sistem Informasi Monitoring Siswa Bermasalah Berbasis Web dan SMS Gateway" [Online]. Tersedia di http://ppta.stikom.edu/

8. Handayani, Suci Wuri, (2009)"Upaya Guru Bimbingan Dan Konseling Dalam Mengatasi Siswa Bermasalah" [Online]. Tersedia di http://digilib.uin-suka.ac.id/

9. Ikhsan,(2012) "Sistem Informasi Pengolahan Data Siswa". [Online]. Tersedia di http://repository.uinsuska.ac.id/

10. Munawir, Arip, (2012) "Sistem Pakar Konsultasi Siswa Bermasalah". [Online]. Tersedia di http://elibrary.if.uinsgd.ac.id/ 